\title{
Litter quality of broiler fed with to different levels of sulfur amino acid
}

Genilson Bezerra de Carvalho - Lindolfo Dorcino dos Santos Neto •

Julyana Machado da Silva Martins - Nikoly Maria Pereira •

Michelly Barbosa Falleiros • Emmanuel Arnhold • Marcos Barcellos Café

GB Carvalho (Corresponding author) - LD Santos Neto JMS Martins - E Arnhold - MB Café

Departamento de Zootecnia, Escola de Veterinária e Zootecnia, Universidade Federal de Goiás (EVZ/UFG), Campus Samambaia, Avenida Esperança, s/n, Campus Universitário, CEP: 74.690.900, Goiânia, GO, Brazil. email: ge.nilson.bezerra@hotmail.com

\author{
NM Pereira - MB Falleiros \\ Campus São Luiz de Montes Belos, Universidade Estadual de \\ Goiás (UEG), São Luiz de Montes Belos, GO, Brazil.
}

Received: October 18, 2017 - Accepted: December 29, 2017

\begin{abstract}
The objective of this study was to determine the effect of sulfur amino acid (methionine+cystine) supplementation included in the diet of broiler chickens raised under Brazilian commercial conditions on the concentration of ammonia gas, moisture, $\mathrm{pH}$, temperature, and nitrogen excretion in litter on the 14th, 28th, and 42nd day of breeding. A total of 900 male chicks of the Cobb500 line were used, distributed in a completely randomized design with five treatments, with six replicates of 30 birds. A basal diet (without methionine) was formulated and was supplemented with DL-methionine $(0.072,0.168,0.239,0.311 \%$ and 0.058 , $0.134,0.192,0.250 \%$ for days 1 to 21 and days 22 to 42 of breeding respectively) replacing the corn starch in order to achieve the desirable digestible methionine + cysteine levels (0.545 (basal diet), 0.616, 0.711, 0.782 and $0.853 \%)$ and (0.514 (basal diet); $0.571 ; 0.647 ; 0.704$ and $0.761 \%$ and digestible methionine + cysteine for the phase 1 to 21 and 22 to 42 days of breeding, respectively. There was no significant effect on the temperature and concentration of ammonia gas in any of the phases evaluated. Met + cys supplementation influenced moisture and $\mathrm{pH}$ of litter in all the evaluated phases. For nitrogen, a significant effect was observed at 14 days, not exhibiting effects during the other phases, suggesting that nitrogen excretion increases with increasing levels of met + cys in the diet for up to 14 days.
\end{abstract}

Keywords: crystalline amino acid, poultry, litter, methionine+cystine

\section{Introduction}

A major problem in the poultry industry concerns amino acid nutrition, of which poultry require a perfect balance. Imbalances influence the quality of the breeding environment, and could be responsible for excess nutrient deposition in litter, which in turn may impact the environment.

Methionine is the first limiting amino acid in corn- and soybean-based poultry diets (Kim et al 2006; Wen et al 2014; Zhang et al 2015). The nitrogen and sulfur atoms that constitute part of the methionine structure may, upon its breakdown, yield odoriferous volatile compounds in henhouses, such as mercaptan, hydrogen sulfide and dimethyl sulfide, phenol, cresol, propionic acid, and butanoic acid, through the microbial decomposition of the litter (Pillai 2011; Murphy et al 2014).

In Brazil, broiler chicken litter is commonly used in the fertilization of pastures and of crops such as eucalyptus, coffee, oranges, and vegetables. Its application provides nutrients such as $\mathrm{P}, \mathrm{K}$, and $\mathrm{N}$, as well as other micro- and macro-nutrients; an average unit of litter contains $4 \% \mathrm{~N}$ (Assity-Duffey et al 2015). Excess $\mathrm{N}$ excretion by poultry arises mainly from dietary amino acids, and may increase the volatilization of ammonia from animal production systems, which can affect air quality (Carter e Kim 2013).

Factors such as litter moisture, $\mathrm{pH}$, and temperature influence microbial aerobic degradation reactions, which convert uric acid to ammonia and carbon dioxide, which are found in henhouses ( $\mathrm{Li}$ 2006). The litter moisture level is critical in hen house management, as it influences the severity and incidence rate of injuries in carcasses, and controls the volatilization of ammonia gas, since increased moisture enhances its release (Qiu e Guo, 2010).

The accumulation of ammonia and fecal matter raises the litter $\mathrm{pH}$, which typically ranges between 7.0 and 8.5 (Rehbeger 2002). pH values above 7.0, when combined with high moisture, typically stimulate bacterial growth in the litter and increase ammonia production (Traldi et al 2007). Ammonia levels should be kept below 10 ppm in all breeding stages (Cobb-Vantress 2008). 
Variables such as $\mathrm{pH}$, moisture, temperature, nitrogen excretion, and concentration of ammonia gas in poultry litter, and their indirect influence on performance and direct influence on the quality of the breeding environment, render their evaluation under different nutritional conditions important.

The present study aimed to determine the effect of sulfur-containing amino acid supplementation (methionine+cysteine) in the diet of broiler chickens (bred under Brazilian commercial conditions) on the concentration of ammonia gas, moisture, $\mathrm{pH}$, temperature, and nitrogen excretion in litter after 14,28 , and 42 days of breeding.

\section{Materials and Methods}

The experiment was conducted between December 2014 and January 2015 at the Industrial Aviary of the Department of Animal Science, School of Veterinary and Animal Science, Federal University of Goiás in Goiânia, Goiás, Brazil (Latitude 16²0'43"S, longitude 49¹5'14"W, altitude $749 \mathrm{~m}$ ). Nine-hundred male Cobb500 broiler chicks were distributed in a completely randomized design of five treatments, each with six replicates of 30 birds.

This study was conducted in strict accordance with the recommendations of the Guide for the Care and Use of Laboratory Animals of the National Institutes of Health. The protocol procedures with experimental animal use was approved by the Ethics Committee for Animal Experimentation of the Federal University of Goiás (Goiás, Brazil), under number 010/2015.

The birds were housed in 30 individual cages measuring $1.80 \times 1.60 \mathrm{~m}\left(2.88 \mathrm{~m}^{2}\right)$, mounted in the central area of the negative pressure industrial henhouse measuring $12 \times 125 \mathrm{~m}\left(1,500 \mathrm{~m}^{2}\right)$, containing seven exhaust fans, a misting system, and an air inlet with evaporative plate. The configuration of the hen house also included masonry side guard rails measuring $0.40 \mathrm{~m}$ in height, and a 2.80 meter-high wire mesh, with a ceiling height of $3.20 \mathrm{~m}$, in an east-west orientation. The birds were raised according to Brazilian trading conditions.

Each cage contained a water dispenser with 10 nippletype outlets, plus a chick- or adult-appropriate tube bird feeder (for ages of 1-7 and 8-42 days, respectively). The ratios of feeder and water dispenser per number of birds were 1:30 and $1: 3$, respectively. The birds were vaccinated in the hatchery against Marek's disease, and against Gumboro disease through drinking water at 14 days of age. Throughout the experimental period, the birds were provided feed and water "ad libitum", and raised following the lighting, temperature, moisture, and management recommendations of the Cobb-Vantress Management Guide (2008).

The control feed was not supplemented with the addition of DL-Methionine (99\%). The methionine+cysteine
(\%) content was acquired solely from the ingredients used in the feed and was thus the lowest. The experimental feeds were supplemented with increasing DL-Methionine levels, $(0.00$, $0.072,0.168,0.239,0.311 \%$ and $0.00,0.058,0.134,0.192$, $0.250 \%$ in the initial and growth phases respectively) which replaced the inert material (corn starch) in the basal feed, resulting in experimental feeds containing $(0.545 \%$ - basal diet; $0.616 \%, 0.711 \% ; 0.782 \%, 0.853 \%)$ and $(0.514 \%$ - basal diet, $0.571 \%, 0.647 \%, 0.704 \%, 0.761 \%$ ) of digestible methionine+cystine in the initial and growth phases (Table 1), respectively.

The diets were based on corn and soybean meal and formulated according to the nutritional recommendations of the supplier, based on (Rostagno et al 2011).

The first batch of rice husk litter with a height of 8-10 $\mathrm{cm}$ was used. The litter was collected after 14, 28, and 42 days of breeding and analyzed for moisture, $\mathrm{pH}$, volatilized ammonia, and total nitrogen.

The temperature evaluation was performed in loco using a Non-Contact Infrared Thermometer with Laser Targeting (Cen-tech ITEM 69465). The procedure to determine the $\mathrm{pH}$ and moisture, volatilized ammonia, and total nitrogen contents involved collecting litter at six different points in each box separately, immediately after temperature evaluation, avoiding the areas adjacent to and below the feeding tubes and water dispensers.

Possible alterations in moisture, $\mathrm{pH}$, and ammonia content measurements were circumvented by immediate analysis after collection in the Food Analysis Laboratory of the DPA/EVZ, UFG-Goiânia-GO. The $\mathrm{pH}$ was measured using a digital $\mathrm{pH}$ meter, PM608 ANALION®, according to the methodology described by (Oliveira et al 2003).

The amount of volatilized ammonia in the litter was determined using the method described by (Hernandes et al 2001), using the formula: $\mathrm{A}=\mathrm{V} \times 17 \times 0.05$, wherein $\mathrm{A}=$ amount of volatilized ammonia $(\mathrm{mg} / 100 \mathrm{~g}), \mathrm{V}=$ volume of $\mathrm{H} 2 \mathrm{SO} 4$ used for titration $(\mathrm{mL}) ; 17=$ molecular weight of ammonia, and $0.05=\mathrm{H} 2 \mathrm{SO} 4$ normality. A 100-g sample was used for ammonia determination.

Litter samples were ground after pre-heating, and subsequently subjected to moisture and nitrogen determination. The moisture content was determined according to the recommendations by the Ministry of Agriculture (Brasil 1992).

The litter nitrogen content was determined according to the Dumas (1831) method using an automated apparatus (Leco) at the Food Analysis Laboratory of the São Paulo State University "Júlio de Mesquita Filho" UNESP Jaboticabal Campus, SP.

An analysis of variance (ANOVA) was performed to assess the significance of treatment effects. Upon significant difference between treatments, a polynomial regression analysis $(\mathrm{P}<0.05)$ was applied using $\mathrm{R}$ computer software. 
Table 1 Percentage composition and nutritional values of the experimental diets for broilers.

\begin{tabular}{|c|c|c|}
\hline Ingredients (\%) & Initial phase (1 to 21 days) & Growth phase ( 22 to 42 days) \\
\hline Corn $(\%)$ & 62.99 & 64.56 \\
\hline Soybean meal $45.5 \%(\%)$ & 28.38 & 24.56 \\
\hline Meat and bone meal $44 \%(\%)$ & 3.20 & 2.60 \\
\hline Poultry by-Product meal (\%) & 2.00 & 2.67 \\
\hline Limestone $37 \%(\%)$ & 0.62 & 0.65 \\
\hline Salt (\%) & 0.40 & 0.24 \\
\hline Poultry Fat (\%) & 1.33 & 3.81 \\
\hline DL-Methionine 99\% (\%) & 0.00 & 0.00 \\
\hline Biolys $70 \%(\%)$ & 0.40 & 0.34 \\
\hline L-Threonine $98 \%(\%)$ & 0.10 & 0.07 \\
\hline Choline $75 \%(\%)$ & 0.06 & 0.03 \\
\hline Others $(\%)$ & 0.13 & 0.13 \\
\hline $\operatorname{Starch}(\%)$ & 0.29 & 0.24 \\
\hline Mineral Supplement ${ }^{1}(\%)$ & 0.05 & 0.05 \\
\hline Vitamin Supplement ${ }^{2}(\%)$ & 0.05 & 0.05 \\
\hline Total (\%) & 100.0 & 100.0 \\
\hline \multicolumn{3}{|l|}{ Calculated composition } \\
\hline Metabolizable Energy (kcal/kg) & 3109 & 3300 \\
\hline Crude Protein $(\%)$ & 21,803 & 20,21 \\
\hline Calcium (\%) & 0,952 & 0,903 \\
\hline Available Phosphorus (\%) & 0,451 & 0,421 \\
\hline Digestible Methionine+Cysteine (\%) & 0,545 & 0,514 \\
\hline Digestible Lysine (\%) & 1,190 & 1,058 \\
\hline Digestible Threonine (\%) & 0,749 & 0,066 \\
\hline Sodium $(\%)$ & 0,201 & 0,190 \\
\hline
\end{tabular}

${ }^{1}$ Mineral supplement per kg of feed (Mineral mix): Mn, $60 \mathrm{~g} ; \mathrm{Fe}, 80 \mathrm{~g} ; \mathrm{Zn}, 50 \mathrm{~g} ; \mathrm{Cu}, 10 \mathrm{~g} ; \mathrm{Co}, 2 \mathrm{~g} ; \mathrm{I}, 1 \mathrm{~g}$; vehicle up to $500 \mathrm{~g} .{ }^{2} \mathrm{Vitamin}$ supplement per kg of feed (Protein mix): Vit. A - 15,000,000 IU; Vit. D3 - 1,500,000 IU; Vit. E - 15,000 IU; Vit. B1 - 2.0 g; Vit. B2 - 4.0 g; Vit B6 - 3.0 g; Vit. B12 - 0.015 g; Nicotinic acid - 25 g; Pantothenic Acid - 10 g; Vit. K3 - 3.0 g; Folic acid - 1.0 g; Zinc bacitracin - 10 g; Selenium - 250 mg; vehicle up to 1,000 g.

Table 2 Moisture, temperature, $\mathrm{pH}$, nitrogen, and ammonia concentration in a litter of 14-day-old broilers subjected to different levels of digestible met+cys.

\begin{tabular}{|c|c|c|c|c|c|}
\hline \multirow[t]{2}{*}{ Met+cys levels (\%) } & \multicolumn{5}{|c|}{ Variables } \\
\hline & Moisture & $\begin{array}{c}\text { Litter } \\
\text { temperature }\end{array}$ & pH & Nitrogen & Ammonia \\
\hline Basal & 9.3167 & 24.4667 & 7.2950 & 1.9050 & 1.3917 \\
\hline 0.616 & 12.4100 & 24.9333 & 7.2217 & 2.0050 & 1.4050 \\
\hline 0.711 & 11.9783 & 24.5000 & 7.0550 & 2.4267 & 1.9850 \\
\hline 0.782 & 12.1817 & 24.7667 & 7.1600 & 2.2033 & 1.8150 \\
\hline 0.853 & 10.7733 & 24.9500 & 6.9950 & 2.4383 & 1.6167 \\
\hline $\mathrm{CV} \%$ & 19.50 & 2.59 & 3.34 & 14.57 & 29.62 \\
\hline Regression & $* *$ & ns & $*$ & $*$ & ns \\
\hline Variables & \multicolumn{4}{|c|}{ Regression equation } & Effect \\
\hline Moisture & \multicolumn{2}{|c|}{$\hat{\mathrm{Y}}=-38.4347+142.3352 \mathrm{x}-99.3523 \mathrm{x}^{2}$} & \multicolumn{2}{|c|}{$\mathrm{R}^{2}=0.82$} & Quadratic \\
\hline $\mathrm{pH}$ & \multicolumn{2}{|c|}{$\hat{Y}=7.7447-0.8545 x$} & \multicolumn{2}{|c|}{$\mathrm{R}^{2}=0.74$} & Linear \\
\hline Nitrogen & \multicolumn{2}{|c|}{$\hat{Y}=1.0363+1.6529 x$} & \multicolumn{2}{|c|}{$\mathrm{R}^{2}=0.70$} & Linear \\
\hline
\end{tabular}

$\mathrm{CV} \%$ : Coefficient of Variation. *,** Linear and Quadratic effect with $(\mathrm{P}<0.05)$, respectively.

\section{Results and Discussion}

The litter temperature, $\mathrm{pH}$, moisture, concentrationof ammonia, and total nitrogen excretion content on the $14^{\text {th }}$ day of breeding for poultry fed with different levels of digestible methionine+cystine are shown in Table 2.
There was an influence $(\mathrm{P}<0.05)$ of digestible met+cys levels on nitrogen excretion, moisture, and $\mathrm{pH}$ of the litter (Table 1; Figures 1A, B, and C, respectively). 


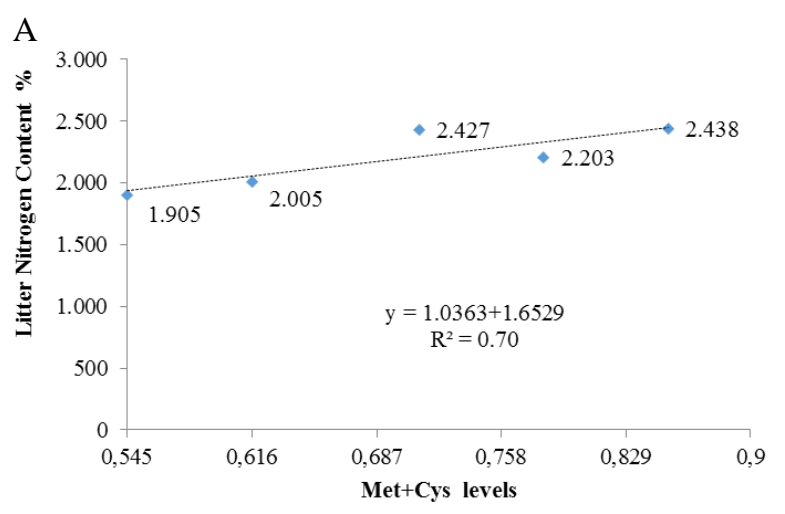

B

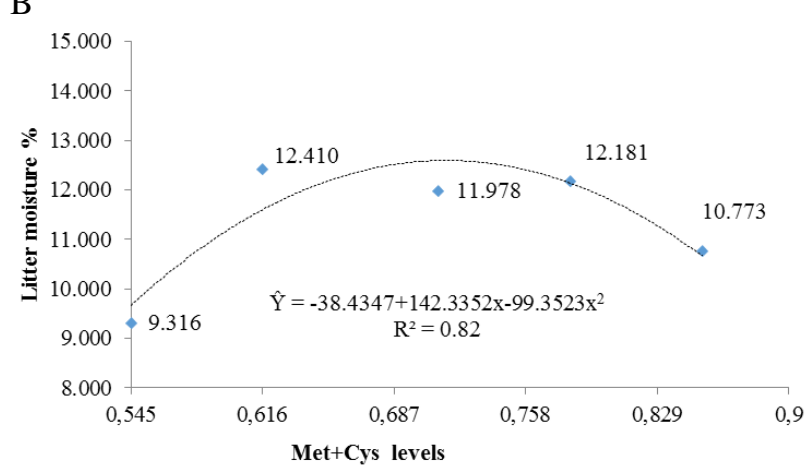

C

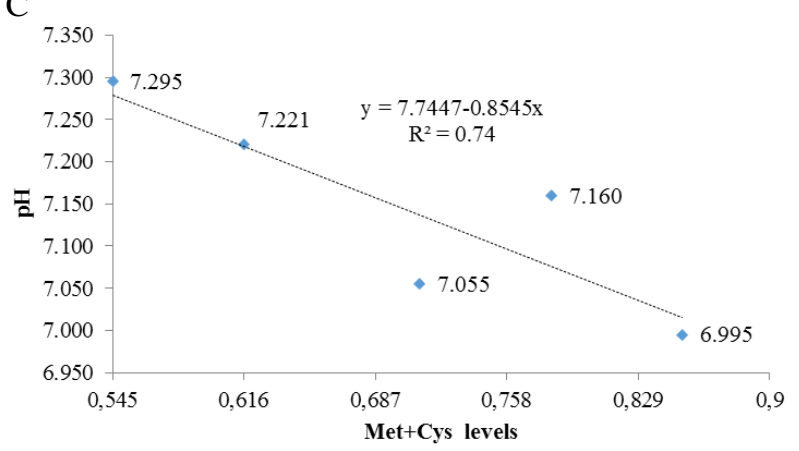

Figure 1 Results of the nitrogen concentration (A), moisture (B), and $\mathrm{pH}(\mathrm{C})$ in litter of 14-day-old broilers bred with different levels of digestible methionine+cystine.

In Figure 1A, there is a linear correlation between digestible met + cys content and nitrogen excretion $(\hat{\mathrm{Y}}=1.0363$ $+1.6529 x ; R^{2}=0.70$ ), showing that an increase in digestible met+cys content increases nitrogen excretion in the litter.

The results suggest that the presence of non-starch polysaccharides (NSPs), which are plant cell wall components, present in corn and also in greater amounts in soybeans, contributed to imbalances in dietary amino acid, enhancing $\mathrm{N}$ excretion in the litter. The lack of one dietary amino acid may have enhanced the catabolism of other amino acids, and consequently the higher nitrogen excretion at this phase.

Non-ruminant animals acquire nitrogen from their diet in the form of proteins and other foodstuff (Bergen e Wu
2009). Protein digestion in poultry yields amino acids and peptides, which are, in part, absorbed by the organism and used in new protein synthesis, and in part, eliminated by the kidneys (Corzo et al 2011). Thus, poultry excretion primarily serves to eliminate nitrogenous substances (Donsbough et al 2010); uric acid is the primary metabolite excreted in urine (as a whitish paste).

Excess amino acids (i.e. in levels above requirements) are deaminated, and nitrogen $(\mathrm{N})$ is excreted as uric acid (Namroud et al 2008). Amino acid shortage can enhance the catabolism of other amino acids (Bertechini, 2006). Excess or insufficient supplementation of dietary methionine increases nitrogen excretion and environmental emissions (Kim et al 2006). Nitrogen excretion can be decreased by adapting the amount of protein in feed to the requirements of the different phases of broiler breeding (Oviedo-Rondón, 2008; Dozier et al 2008).

NSPs adversely compromise the bioavailability of important nutrients to poultry such as $\mathrm{N}$ and $\mathrm{P}$, which are consequently eliminated in excess in the litter and which become harmful to the environment (Alvarenga et al 2011).

Regression analysis showed a quadratic effect of digestible met + cys levels on litter moisture $(\hat{\mathrm{Y}}=-38.4347+$ $\left.142.3352 \mathrm{x}-99.3523 \times 2 ; \mathrm{R}^{2}=0.82\right)$. Moisture increased with the digestible met+cys content; according to the obtained equation, the largest moisture content was observed in diets supplemented with $0.716 \%$ digestible methionine+cysteine, reaching a plateau from then onwards (Figure 1B).

Litter moisture is a major concern in broiler production due to its negative impact on poultry health, well-being, and productive performance (Owada et al 2007; Qiu e Guo, 2010; Garcia et al 2012; Sharma et al 2016). Multifactorial causes influence litter moisture in an industrial henhouse, stemming from interactions between bird nutrition, handling, and intestinal health (Oviedo-Rondón, 2008). Sodium, chlorine, potassium, and dietary fiber levels; the digestibility of dietary protein; water consumption; inadequate use of phytase in feed; type of water dispenser; and ventilation, among others, are noteworthy factors that contribute to litter moisture (OviedoRondón, 2008; Qiu e Guo, 2010).

An increase in dietary protein enhances the consumption of water and consequently its content in excreta (Ziaein et al 2007; Collett, 2012). This phenomenon becomes more relevant when the dietary protein content is higher or lower than the desired level, i.e., when the amino acid profile is imbalanced (Collet, 2006; Namroud et al 2009). In such cases, excess amino acids-which are not used in synthetic pathways - should be catabolized, with nitrogen eliminated as uric acid through excreta and urine (Kim et al 2006; Van der Hoeven-Hangoor et al 2014), which consequently increases water loss.

In birds, the elimination of nitrogen as uric acid employs specific enzymes, with a concomitant loss of water; 
this represents an important adaptation of birds to the terrestrial environment (Devilin, 2011; Capitelli e Crosta, 2013). Elevated nitrogen excretion correlates with higher moisture content in excreta (Namroud et al 2008; Van der Hoeven-Hangoor et al 2014).

Thus, the present study indicates that the low litter moisture in treatments with lower dietary digestible met+cys levels can be ascribed to the lower excretion volume of uric acid.

The hydrogen potential $(\mathrm{pH})$ (Figure 1C) correlated in a negative linear manner with dietary digestible methionine+cysteine content $(\mathrm{P}<0.05)$, i.e., the former decreased as the latter increased. The highest digestible met+cys content $(0.853 \%)$ yielded the lowest $\mathrm{pH}$ value (6.99).

Increased methionine+cysteine levels exerted no effect $(\mathrm{P}<0.05)$ on litter temperature and concentration of ammonia of 14-day-old broilers. The conversion of nitrogen to ammonia in excreta is related to litter temperature, moisture, and $\mathrm{pH}$, and the ventilation rate of the breeding environment (Miles, 2008). In poultry manure, the dominant nitrogen form is the ammonium ion (NH4+), which is converted into ammonia (NH3+) with increasing $\mathrm{pH}$ and humidity (Oviedo-Rondón, 2008).
The concentration of ammonia gas tends to increase with an increase in excreta moisture content; several microbial species depend on water and are activated by the increased litter moisture. Some studies have found that the water content in litter affects microbial activity (Wadud et al 2012), ammonia emissions, and odors (Miles et al 2011; Sharma et al 2015).

Equipment that improve hen house internal conditions in broiler breeding, such as misting systems, are employed virtually only in the final breeding phase; the fact that water consumption in the first breeding phase is minimal, generated a consensus that the use of water in poultry facilities is lower in the first weeks of birds' lives, thereby reducing the excreta volume (uric acid + water) produced.

Thus, the present study indicates that litter moisture content is below the ideal value for enhanced microbial proliferation, yielding an insignificant ammonia concentration.

An analysis of Table 3 and Figures $2 \mathrm{~A}$ and $\mathrm{B}$ found statistical differences for litter moisture and $\mathrm{pH}$ among the variables evaluated in 28-day-old-birds.

Table 3 Moisture, temperature, $\mathrm{pH}$, nitrogen, and ammonia concentration in litter at a broiler age of 28 days, subjected to different levels of digestible met+cys.

\begin{tabular}{|c|c|c|c|c|}
\hline \multirow{2}{*}{ Met+cys levels (\%) } & \multicolumn{4}{|c|}{ Variables } \\
\hline & Moisture & Litter temperature & pH & Ammonia \\
\hline Basal & 12.1583 & 27.8833 & 8.3200 & 5.1033 \\
\hline 0.571 & 17.0833 & 27.5000 & 8.3040 & 5.0883 \\
\hline 0.647 & 17.6517 & 28.0500 & 8.2033 & 4.8900 \\
\hline 0.704 & 17.2833 & 27.8500 & 8.0983 & 4.5917 \\
\hline 0.761 & 18.1633 & 27.4000 & 8.1417 & 4.2683 \\
\hline $\mathrm{CV} \%$ & 21.73 & 4.16 & 1.93 & 30.54 \\
\hline Regression & $*$ & ns & $*$ & $\mathrm{~ns}$ \\
\hline Variables & \multicolumn{3}{|c|}{ Regression Equation } & Effect \\
\hline Moisture & \multicolumn{3}{|c|}{$\hat{\mathrm{Y}}=4.0411+19.4353 \mathrm{x}\left(\mathrm{R}^{2}=0.60\right)$} & Linear \\
\hline $\mathrm{pH}$ & \multicolumn{3}{|c|}{$\hat{\mathrm{Y}}=8.7875-0.8994 \mathrm{x} \quad\left(\mathrm{R}^{2}=0.84\right)$} & Linear \\
\hline
\end{tabular}

CV\%: Coefficient of Variation. *, ** Linear and Quadratic effect with $(\mathrm{P}<0.05)$, respectively.

Litter moisture (Figure 2A) correlated linearly $(\mathrm{P}<$ 0.05) with increased levels of digestible dietary methionine+cysteine.

Poultry whose diets were supplemented with the highest levels of digestible met+cys consumed more water and eliminated larger volumes of uric acid and water in excreta, thereby increasing litter moisture.

There is evidence that the consumption of water affects the nitrogen metabolism of non-ruminant animals. (Bressani e Braham, 1964) assumed that a high consumption of water (either ad libitum or forced) in non-ruminant animals led to a decrease in nitrogen retention.

For $\mathrm{pH}$ values, a negative linear correlation was observed $(\mathrm{P}<0.05)$, i.e., its value in the litter decreased as dietary digestible met+cys increased. The $\mathrm{pH}$ value remained in the alkaline region in all treatments after 28 days of breeding, which compromised the internal conditions of the henhouse. One of the most important factors that can affect NH3 release is litter pH (Choi e Moore, 2008). Small quantities of ammonia are released under acidic $\mathrm{pH}$; however, $\mathrm{pH}$ values above 8.0 favor the decomposition of uric acid (C5H4N4O3) (Hristov et al 2011; Behera et al 2013). H+ ions and $\mathrm{pH}$ values below 7.0 decrease the $\mathrm{NH} 3 / \mathrm{NH} 4+$ ratio, leading to a reduction of nitrogen losses from ammonia volatilization, as the ammonium ion is non-volatile (Hristov et al 2011; Behera et al 2013). pH values below 7.0, in addition to reducing the litter bacterial load, reduce ammonia volatilization, thereby improving the 
environmental conditions of the aviary (Oviedo-Rondón, 2008; Carvalho et al 2011).
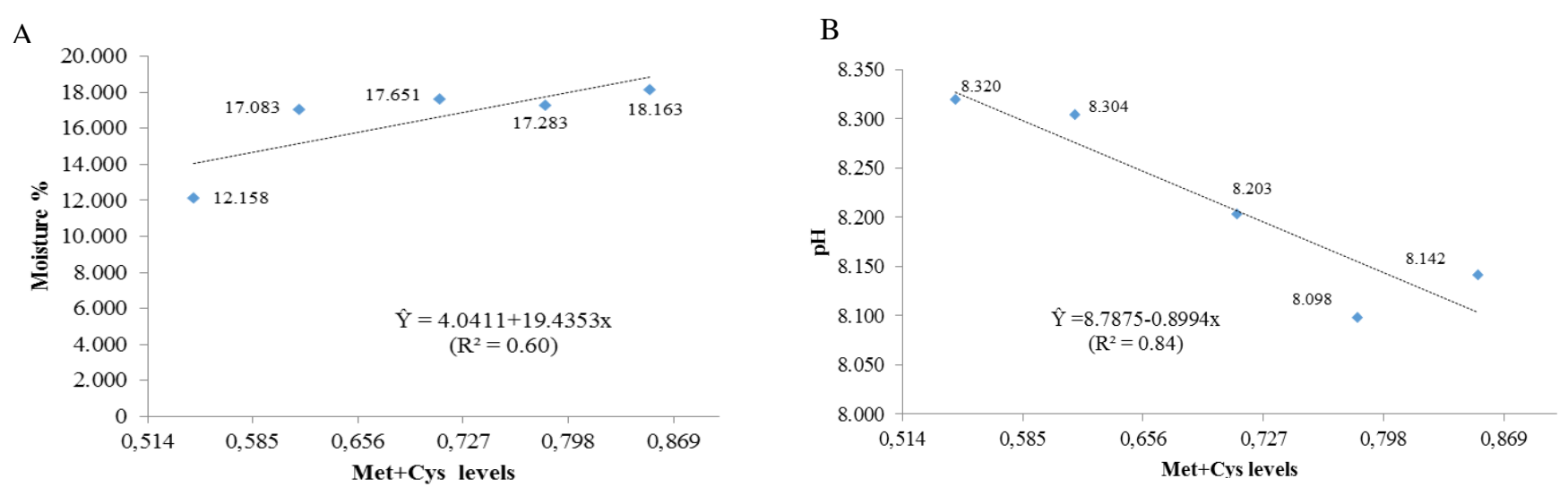

Figure 2 Litter moisture (A) and pH (B) after 28 days of broiler age, subjected to different levels of digestible methionine+cystine.

The present study showed that an alkaline $\mathrm{pH}$ valuefavorable to microbial growth in the litter-did not compromise ammonia concentration, and it is thus likely that this increase in $\mathrm{pH}$ stemmed from the increased accumulation of excreta and the gradual increase of litter moisture as poultry breeding progressed, and not from the dietary digestible met+cys content.
No significant difference was found $(\mathrm{P}>0.05)$ in ammonia levels between the different treatments at the 28th day of breeding (Table 2).

The litter nitrogen content, moisture, $\mathrm{pH}$, and the ammonia volatilization potential at the 42 nd day of breeding are described in Table 4.

Table 4 Litter moisture, temperature, $\mathrm{pH}$, nitrogen, and ammonia concentration of 42-day-old-broilers subjected to different levels of digestible met+cys.

\begin{tabular}{|c|c|c|c|c|c|}
\hline \multirow[b]{2}{*}{ Met+cys levels (\%) } & \multicolumn{5}{|c|}{ Variables } \\
\hline & Moisture & $\begin{array}{c}\text { Litter } \\
\text { temperature }\end{array}$ & pH & Nitrogen & Ammonia \\
\hline Basal & 20.6667 & 29.1400 & 8.6783 & 3.9500 & 14.8917 \\
\hline 0.571 & 20.6600 & 28.3667 & 8.5567 & 3.8367 & 19.0567 \\
\hline 0.647 & 19.6967 & 29.0833 & 8.6967 & 3.8567 & 14.0133 \\
\hline 0.704 & 23.3550 & 27.9667 & 8.1367 & 3.7233 & 11.8017 \\
\hline 0.761 & 27.6050 & 28.7000 & 8.6080 & 3.8533 & 14.9917 \\
\hline $\mathrm{CV} \%$ & 18.98 & 2.44 & 1.04 & 6.04 & 33.00 \\
\hline Regression & $*$ & Ns & $* *$ & $\mathrm{~ns}$ & ns \\
\hline Variables & \multicolumn{3}{|c|}{ Regression Equation } & \multicolumn{2}{|c|}{ Effect } \\
\hline Moisture & \multicolumn{3}{|c|}{$\hat{\mathrm{Y}}=111.4610-312.2721 \mathrm{x}+65.4141 \mathrm{x}^{2}\left(\mathrm{R}^{2}=0.95\right)$} & \multirow{2}{*}{\multicolumn{2}{|c|}{$\begin{array}{l}\text { Quadratic } \\
\text { Quadratic }\end{array}$}} \\
\hline $\mathrm{pH}$ & $\hat{\mathrm{Y}}=12$. & $599 x+7.2250 x^{2}$ & $\left(\mathrm{R}^{2}=0.13\right)$ & & \\
\hline
\end{tabular}

CV\%: Coefficient of Variation. *, ** Linear and Quadratic effect with $(\mathrm{P}<0.05)$, respectively.

The methionine+cysteine content on the litter's hydrogenionic potential $(\mathrm{pH})$ and moisture after 42 days exhibited a quadratic effect $(\mathrm{P}<0.05), \hat{\mathrm{Y}}=12.0161-10.1599 \mathrm{x}$ $+7.2250 \mathrm{x}^{2}\left(\mathrm{R}^{2}=0.13\right), \hat{\mathrm{Y}}=111.4610-312.2721 \mathrm{x}+$ $265.4141 \mathrm{x}^{2},\left(\mathrm{R}^{2}=0.95\right)$, with a positive trend up to $0.703 \%$ and $0.588 \%$ of methionine+cysteine, respectively (Table 4 and Figures $3 \mathrm{~A}$ and B).

A litter with moisture content below 20\% increases dust concentration within the facility, which irritates the respiratory system of birds and predisposes them to the development of infection. On the other hand, excessive litter moisture (above 35\%) may cause health and wellbeing issues in birds, increased incidence of breast lesions, skin burns, pododermatitis, convictions, and loss of quality in carcasses (Nagaraj et al 2007; Traldi et al 2007; Cobb-Vantress, 2008; Shepherd e Fairchild, 2010).

There was no influence of digestible met+cys content $(\mathrm{P}<0.05)$ on nitrogen excretion, ammonia concentration, and litter temperature on the 42 nd day of breeding.

In the present study, an increase in litter temperature was observed throughout the evaluation period. This increase in litter temperature is related to the duration that birds spend lying down as they age. 
The concentration of ammonia in the litter was not significantly affected $(\mathrm{P}<0.05)$ in any of the evaluated periods; however, ammonia volatilization gradually increased with bird age. This increased concentration of ammonium in the litter is probably related to excreta produced with the increasing bird age, moisture, and litter $\mathrm{pH}$ alkalinity.

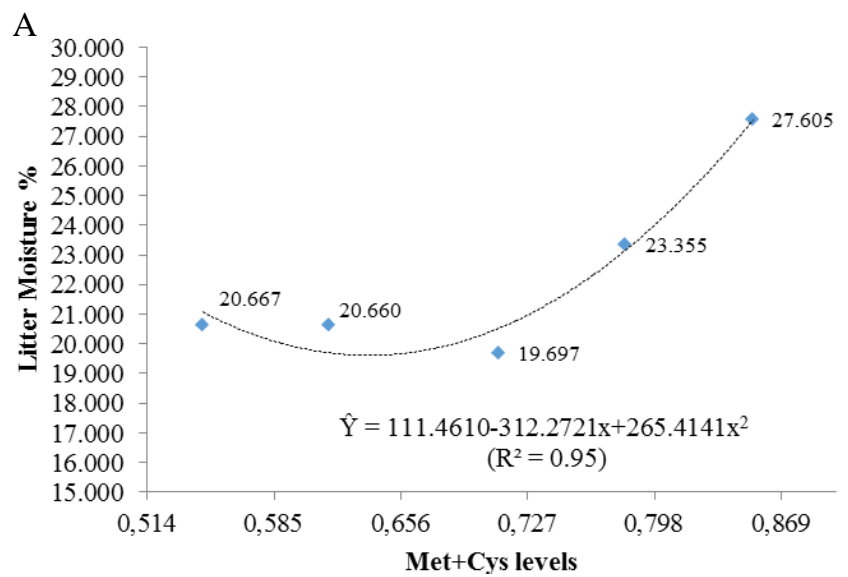

B

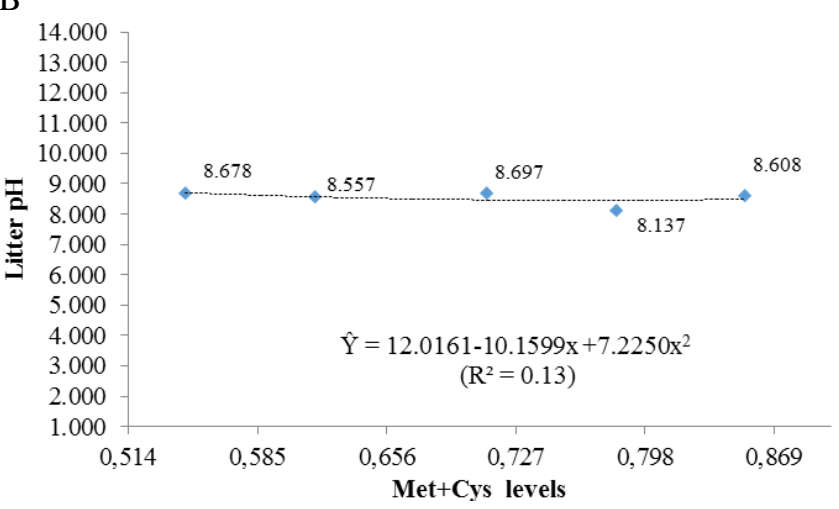

Figure 3 Litter moisture (A) and $\mathrm{pH}$ (B) after 42 days of broiler age, subjected to different levels of digestible methionine+cysteine.

\section{Conclusions}

Litter temperature and concentration of ammonia gas were not significantly affected in any of the evaluated phases. The different treatments exerted effects on litter moisture and $\mathrm{pH}$ in each evaluated phase. The nitrogen content was significantly affected after 14 days, but not in the remaining stages, suggesting that nitrogen excretion increases with increasing levels of dietary met+cys up to 14 days.

\section{References}

Alvarenga RR, Nagata AK, Rodrigues PB, Zangeronimo MG, Pucci LEA, Hespanhol R (2011) Adição de fitase em rações com diferentes níveis de energia metabolizável, proteína bruta e fósforo disponível para frangos de corte de 1 a 21 dias. Ciência Animal Brasileira 12:602-609.
Assity-Duffey K, Cabrera M, Rema J (2015) Ammonia volatilization from broiler litter: Effect of soil water content and humidity. Soil Science Society of America Journal 79:543-550.

Bertechini AG (2006) Nutrição de Monogástricos, Lavras: Editora UFLA.

Bergen WG, Wu G (2009) Intestinal nitrogen recycling and utilization in health and disease. Recent Advances in Nutritional Sciences 139:821-825.

Behera SN, Sharma M, Aneja VP, Balasubramanian R. (2013) Ammonia in the atmosphere: a review on emission sources, atmospheric chemistry and deposition on terrestrial bodies. Environmental Science and Pollution Research 20:8092-8131.

Brasil (1992) Ministério da Agricultura e Reforma Agrária. Regras para análise da qualidade e produtividade. Brasília: MDA.

Bressani R, Braham JE (1964) Effect of water intake on nitrogen metabolism in dogs. Journal of Nutrition 82:469-474.

Carter SD, Kim HJ (2013) Technologies to reduce environmental impact of animal wastes associated with feeding for maximum productivity. Animal Frontiers 3:42-47.

Capitelli R, Crosta L (2013) Overview of psittacine blood analysis and comparative retrospective study of clinical diagnosis, hematology and blood chemistry in selected psittacine species. Veterinary Clinics of North America: Exotic Animal Practice 16:71120 .

Carvalho TMRD, Moura DJD, Souza ZMD, Souza GSD, Bueno LGDF (2011) Litter and air quality in different broiler housing conditions. Pesquisa Agropecuária Brasileira 46:351-361.

Cobb-Vantress (2008) Manual de manejo de frangos de corte. Guapiaçu: Cobb Vantress.

Collett SR (2012) Nutrition and wet litter problems in poultry. Animal Feed Science and Technology 173:65-75.

Corzo A, Loar II, Kidd MT, Burgess SC (2011) Dietary protein effects on growth performance, carcass traits and expression of selected jejunal peptide and amino acid transporters in broiler chickens. Revista Brasileira de Ciência Avícola 13:139-146.

Choi IH, Moore PA (2008) Effect of various litter amendments on ammonia volatilization and nitrogen content of poultry litter. The Journal of Applied Poultry Research 17:454-462.

Donsbough AL, Powell S, Waguespack A, Bidner TD, Southern LL (2010) Uric acid, urea, and ammonia concentrations in serum and uric acid concentration in excreta as indicators of amino acid utilization in diets for broilers. Poultry Science 89: 287-294.

Dozier WA III, Kidd MT, Corzo A (2008) Dietary amino acid responses of broiler chickens. Journal of Applied Poultry Research17:157-167.

Devilin TM (2011) Manual de bioquímica com correlações clinicas. In:__. Metabolismo de aminoácidos. São Paulo (SP): Blücher, $732-736$.

García RG, Almeida Paz ICL, Caldara FR, Nääs IA, Pereira DF, Ferreira VMOS (2012) Selecting the most adequate bedding material for broiler production in Brazil. Revista Brasileira de Ciência Avícola $14: 121-127$.

Hernandes R, Cazetta JO (2001) Simple and accessible method to determine liberated ammonia from the broiler litter. Revista Brasileira de Zootecnia 30:824-829. 
Hristov AN, Hanigan M, Cole A, Todd R, Mcallister TA, Ndegwa PM, Rotz A (2011) Review: ammonia emissions from dairy farms and beef feedlots 1. Canadian journal of animal science 91:1-35.

Kim WK, Froelich CA, Patterson PH, Ricke SC (2006) The potential to reduce poultry nitrogen emissions with dietary methionine or methionine analogues supplementation. World's Poultry Science Journal 62:338-353.

Li H (2006) Ammonia emissions from manure belt laying hen houses and manure storage, PhD Diss. Iowa State University, Ames.

Miles DM (2008) Vertical stratification of ammonia in a broiler house. The Journal of Applied Poultry Research 17:348-353.

Miles DM, Rowe DE, Cathcart TC (2011) Litter ammonia generation: Moisture content and organic versus inorganic bedding materials. Poultry Science 90:1162-1169.

Murphy KR, Parcsi G, Stuetz RM (2014) Non-methane volatile organic compounds predict odor emitted from five tunnel ventilated broiler sheds. Chemosphere 95:423-432.

Nagaraj M, Wilson CAP, Saenmahayak B, Hess JB, Bilgili SF (2007) Efficacy of a litter amendment to reduce pododermatitis in broiler chickens. The Journal of Applied Poultry Research 16:255-261.

Namroud NF, Shivazad M, Zaghari M (2008) Effects of fortifying low crude protein diet with crystalline amino acids on performance, blood ammonia level, and excreta characteristics of broiler chicks. Poultry Science 87:2250-2258.

Namroud NF, Shivazad M, Zaghari M (2009) Impact of dietary crude protein and amino acids status on performance and some excreta characteristics of broiler chicks during 10-28 days of age. Journal of Animal Physiology and Animal Nutrition 94:280-286.

Oliveira MCD, Almeida CV, Andrade DO, Rodrigues SMM (2003) Teor de matéria seca, $\mathrm{pH}$ e amônia volatilizada da cama de frango tratada ou não com diferentes aditivos. Revista Brasileira de Zootecnia 32:951-954.

Oviedo-Rondón EO (2008) Tecnologias para mitigar o impacto ambiental da produção de frangos de corte. Revista Brasileira de Zootecnia 37(SPE):239-252.

Owada AN, Nääs IDA, Moura DJD, Baracho MDS (2007) Estimativa de bem-estar de frango de corte em função da concentração de amônia e grau de luminosidade no galpão de produção. Engenharia Agrícola 27:611-618.

Pillai S (2011) Intercomparison of headspace sampling methods coupled to TD-GC-MS/O to characterise key odorants from broiler chicken litter. 319p. Dissertation Sydney: University of New South Wales.

Qiu G, Guo M (2010) Quality of poultry litter-derived granular activated carbon. Bioresource Technology 101:379-386.

Rehbeger TC (2002) Controlling litter microorganisms. e- Digest 2:1-6.

Rostagno HS, Albino LFT, Donzele JL, Gomes PC, Oliveira RF, Lopes DC, Ferreira AS, Barreto SLT, Euclides RF (2011) Tabelas brasileiras para aves e suínos: composição de alimentos e exigências nutricionais de aves e suínos. $3^{\text {a } e d i c ̧ a ̃ o, ~ V i c ̧ o s a, ~ M G: ~ U F V . ~}$

Sharma NK, Choct M, Wu SB, Smillie R, Swick RA (2015) Dietary composition affects odour emissions from meat chickens. Animal Nutrition 1:24-29.

Sharma NK, Choct M, Wu SB, Smillie R, Morgan N, Omar AS, Swick RA (2016) Performance, litter quality and gaseous odour emissions of broilers fed phytase supplemented diets. Animal Nutrition 1-8.

Shepherd EM, Fairchild BD (2010) Footpad dermatitis in poultry. Poultry Science 89:2043-2051.

Traldi AB, Oliveira MCD, Duarte KF, Moraes VMBD (2007) Avaliação de probióticos na dieta de frangos de corte criados em cama nova ou reutilizada. Revista Brasileira de Zootecnia 36:660665 .

Van Der Hoeven-Hangoor E, Paton ND, Van De Linde IB, Verstegen MWA, Hendriks WH (2013) Moisture content in broiler excreta is influenced by excreta nutrient contents. Journal of Animal Science 91:5705-5713.

Wen C, Chen X, Chen GY, Wu P, Chen YP, Zhou YM, Wang T (2014) Methionine improves breast muscle growth and alters myogenic gene expression in broilers. Journal of Animal Science 92:1068-1073.

Wadud S, Michaelsen A, Gallagher E, Parcsi G, Zemb O, Stuetz R, Manefield M (2012) Bacterial and fungal community composition over time in chicken litter with high or low moisture content. British Poultry Science 53:561-569.

Zhang S, Wong EA, Gilbert ER (2015) Bioavailability of different dietary supplemental methionine sources in animals. Frontiers in Bioscience (Elite edition) 1:478-490.

Ziaein N, Guy JH, Edwards SA, Blanchard PJ, Ward J, Feuerstein D (2007) Effect of gender on factors affecting excreta dry matter content of broiler chickens. The Journal of Applied Poultry Research $16: 226-233$ 